\title{
Initial Cancer Genetic Counseling Consultation: Change in Counselees' Cognitions and Anxiety, and Association With Addressing Their Needs and Preferences
}

\author{
Arwen H. Pieterse, ${ }^{1 *}$ Margreet G.E.M. Ausems, ${ }^{2}$ Alexandra M. Van Dulmen, ${ }^{1}$ Frits A. Beemer, ${ }^{2}$ \\ and Jozien M. Bensing ${ }^{1,3}$ \\ ${ }^{1}$ NIVEL (Netherlands Institute of Health Services Research), Utrecht, The Netherlands \\ ${ }^{2}$ Department of Medical Genetics, University Medical Centre, Utrecht, The Netherlands \\ ${ }^{3}$ Department of Health Psychology, Utrecht University, Utrecht, The Netherlands
}

\begin{abstract}
The fulfillment of counselees' expectations in cancer genetic counseling and how this affects the outcome of counseling have received little attention so far. This study investigates how the initial consultation influences counselees' cognitions and anxiety, whether counselors address counselees' prior needs and preferences during the visit, and whether addressing needs is associated with a more positive outcome of the visit. One hundred twenty-eight affected and unaffected counselees from families with no known mutation, who were seen by one of fourteen counselors, participated. Pre- and post-visit questionnaires assessed correct knowledge about hereditary breast or colon cancer, perceived personal control (PPC), anxiety (STAI), risk perceptions, and (fulfillment of) needs (QUOTE-gene ${ }^{\text {ca }}$ ). Results demonstrated a pre- to post-visit significant increase in correct knowledge and PPC, and a significant decrease in STAI and risk perceptions. However, marked overestimation of risks persisted. Decrease in STAI and risk perceptions was significantly less pronounced in affected versus unaffected counselees. The majority of counselees were (very) satisfied about the extent to which their needs were addressed, albeit about one-fifth were not regarding emotional matters and explanations about their own cancer risk. Finally, the better counselees perceived their needs to be fulfilled, the significantly higher their PPC and the significantly lower their STAi scores were. Findings suggest that both unaffected and affected counselees should be counseled carefully. Also, a more effective service may be attained if counselors pay more attention to counselees' emotional needs and detail more inheritance and penetrance of mutated genes in relation to counselees' family history. ๑ 2005 Wiley-Liss, Inc.
\end{abstract}

This article contains supplementary material, which may be viewed at the American Journal of Medical Genetics website at http://www.interscience.wiley.com/jpages/1552-4825/suppmat/ index.html.

Grant sponsor: Dutch Cancer Society.

*Correspondence to: Arwen H. Pieterse, NIVEL, P.O. Box 1568, 3500 BN, Utrecht, The Netherlands. E-mail: a.pieterse@nivel.nl

Received 30 August 2004; Accepted 2 May 2005

DOI 10.1002/ajmg.a.30839
KEY WORDS: cancer genetic counseling; needs; initial visit outcome

\section{INTRODUCTION}

One of the achievements of research on human cancer genetics in the past decade was the uncovering of cancer susceptibility genes. Still, genetic testing is limited in its capacity to identify mutation carriers [Wooster and Weber, 2003], let alone to predict illness [Clayton, 2003; Finkler et al., 2003]. Nonetheless, the public seems to perceive genetic testing as a tool for accurately predicting the future [Finkler et al., 2003]. Public understanding of the meaning and implications of pathogenic mutations appears limited [Clayton, 2003] and advances in genomics may have led laypeople to hold unrealistic beliefs about (future) achievements of medicine [Tambor et al., 2002]. Unrealistic expectations, if not dealt with, may hamper successful counseling. Indeed, research within primary care has shown that individual patients differ in their needs and preferences and that eliciting and addressing these needs result in lower psychological distress [Roter, 2000], greater patient satisfaction, and more positive health outcomes [Stewart, 1995; Stewart et al., 2000]. In line with a more individualized approach in the field of medicine, where attention has shifted from what can be offered by medicine towards what the individual patient wants [Bensing, 2000], the question arises in how far what is offered through genetic counseling addresses counselees' needs and preferences, and how this affects the outcome of counseling.

Studies on the impact of genetic counseling for hereditary cancer on counselees' cognitions and psychological well-being showed overall positive effects on distress [Julian-Reynier et al., 1998, 1999; Cull et al., 1999; Bish et al., 2002], risk perception [Cull et al., 1999; Burke et al., 2000; Bish et al., 2002], and knowledge [Lerman et al., 1997; Michie et al., 1997b; Collins et al., 2000; Randall et al., 2001]. However, most research so far has focused on measures of distress, anxiety, and risk perception [Meiser and Halliday, 2002]. A study by Hallowell et al. [1997] showed that almost one-third of unaffected women with a family history of breast/ovarian cancer were disappointed by some aspect of counseling, including not having a DNA-test and not being given enough information. In a similar vein, in a study including various genetic conditions, a sizeable minority of the counselees reported not to have received what they had been expecting [Michie et al., 1998].

Previously [Pieterse et al., 2005], we identified needs and preferences of individuals who are the first in their families to seek counseling for hereditary cancer. Results on the importance attached to the various issues pre-counseling suggested that counselees considered, on average, counselor's sensitive 
communication as most important, as well as receiving explanations on DNA-testing and implications of carrying a mutation in a cancer gene, and explanations about their own risk of (re-)developing cancer. Importance scores were dependent in part on gender, educational level, and personal, and family history of cancer. In this study, it will be investigated (a) what the outcome of the initial cancer genetic counseling visit is in terms of counselees' cognitions (correct knowledge, perceived personal control, and risk perceptions) and anxiety compared to baseline, (b) to what extent, in counselees' perception, genetic counselors address their pre-visit needs and preferences during the visit, and (c) whether fulfilling needs that are perceived as important pre-visit is associated with a more positive outcome of the visit in terms of correct knowledge, perceived personal control, anxiety, and risk perceptions, controlling for pre-visit level.

\section{METHODS}

\section{Participants}

Counselees. Participating counselees were recruited from all new counselees at the Department of Medical Genetics of the University Medical Centre, Utrecht, the Netherlands, between March 2001 and August 2003. Inclusion criteria were referral for hereditary cancer, aged 18 years or older, and being the first in the family to seek genetic counseling. This study is part of a prospective study on communication during genetic counseling in case of hereditary cancer, which included videorecordings of the consultations and a feedback training for counselors [Pieterse et al., 2005, in press]. In this study, data will be reported for counselees who were seen by a counselor before he/she received feedback, to rule out the effects of the training.

Counselors. All clinical geneticists, residents in clinical genetics and genetic nurses providing cancer genetic counseling at the clinic during the study period, participated in the study. All will be referred to as 'counselor.'

\section{Initial Counseling Consultation}

Prior to the initial counseling consultation, counselees are sent a medical questionnaire asking for details about their family history of cancer. If the medical questionnaire is returned prior to the visit, the counselor draws up a pedigree based on the information. During the visit, all details are checked for accuracy. If the medical questionnaire is not returned in time, data are collected during the consultation. Relevant medical data of affected relatives are collected following the initial visit, after written consent is received. During the visit, usually the prevalence of the type of cancer occurring in the family and how often this type of cancer is hereditary are discussed, and inheritance in general is explained. Criteria indicating increased probability of heredity of a genetic form of the disease are clarified, and based on family history an estimation is provided of the likelihood of hereditary cancer running in the family. Possibilities and limitations of diagnostic genetic testing are described and screening recommendations are made. If there is an indication for a DNA-test after the initial visit, a blood sample is drawn from the counselee or a family member. Test results are communicated and discussed in a following consultation. A second visit may also be arranged to discuss pedigree data that were not yet available during the initial consultation. A consultation is ordinarily conducted by one counselor. In a number of cases where one of the counselors has not yet completed his/her training, a clinical geneticist is also present. All counselees receive a summary letter after the consultation, outlining the issues discussed in the visit, with a copy to the GP and referring physician.

\section{Procedure}

Approval of the Medical Ethical Committee of the university hospital was obtained to conduct the present study. The procedure of approaching eligible counselees is detailed elsewhere [Pieterse et al., 2005]. Participants in the study were sent a pre-visit questionnaire within a week before their first consultation, along with an informed consent form, and were asked to complete it before their visit at the clinic. At the start of the consultation, the counselor collected the pre-visit questionnaire and the signed informed consent form. At the end of the consultation, the counselor handed out a second questionnaire, which the counselees were asked to complete within a day after their visit at the clinic. If the post-visit questionnaire was not returned, no reminder was sent to rule out potential bias due to lapse of time. The counselors were asked to fill in a questionnaire after each consultation with a participant.

\section{Pre- and Post-Visit Measures}

The pre-visit questionnaire for counselees contained the QUOTE-gene $^{\text {ca }}$ [Pieterse et al., 2005], a measure of knowledge about hereditary cancer, four measures of risk perception, and standardized measures of perceived personal control and generalized state anxiety. At baseline counselee age, gender, education, referral pathway, type of cancer for which they were seeking counseling, number of affected first- and seconddegree family members, and counselor gender and age were also assessed. Information on whether the counselees were themselves diagnosed with cancer and whether a DNA-test was indicated for them or a relative was collected from their medical file. The post-visit questionnaire for counselees contained the QUOTE-gene ${ }^{\mathrm{ca}}$ and similar measures of knowledge, risk perceptions, perceived personal control, and anxiety as at baseline. The post-visit questionnaire for counselors contained three measures of risk estimation with regard to the counselee they had just seen.

Measurement of preferences and performance: QUOTE-gene ${ }^{\boldsymbol{c a}}$. As described elsewhere [Pieterse et al., 2005], a counselee-based instrument was developed for measuring needs and preferences prior to genetic counseling. Identical items were administered, after the visit, in order to measure the extent to which, during the visit, needs and preferences were fulfilled in counselees' perception. All items were formulated pre-visit as importance statements ('During counseling, the counselor should...'), and post-visit as performance statements ('During counseling, the counselor did ...'), to be answered on a 4-point scale. Pre-visit response options were 1, 'not important'; 2, 'fairly important'; 3, 'important'; and 4, 'extremely important.' Post-visit response options were 1 'too little'; 2 , 'not really enough'; 3 , 'adequate'; and 4 'largely adequate.' Four generic and four cancer-specific needs were identified (Table I). Internal consistencies (Cronbach's alpha) of the various scales were found to be satisfactory.

Knowledge about hereditary cancer. Level of correct knowledge about hereditary breast and colon cancer was assessed using items adapted from Claes et al. [2003]. Only counselees seeking counseling for hereditary breast or colon cancer responded to the corresponding items. All items (see the online Appendix A at http://www.interscience.wiley.com/ jpages/1552-4825/suppmat/index.html) were worded as statements with three response categories (1, 'correct'; 2 , 'incorrect'; 3 , 'don't know'). Total correct knowledge scores were calculated as the number of correct answers on the relevant items (range scores of correct knowledge about hereditary breast and colon cancer were 1-7 and 1-6, respectively). A correct knowledge score irrespective of type of cancer was computed as the mean number of correct answers on the relevant knowledge items (range scale, $0-1$ ). 
TABLE I. Needs as Assessed Using QUOTE-gene ${ }^{\text {ca }}$, Number, and Examples of Items Included in Each Component, Pre- and Post-Visit Internal Consistencies, and Number of Participants Over Which These Were Calculated

\begin{tabular}{|c|c|c|c|c|c|c|}
\hline Need & Items (n) & Examples of items & $\alpha$ (before) & $\mathrm{N}$ & $\alpha$ (after) & $\mathrm{N}$ \\
\hline \multicolumn{7}{|c|}{ Generic needs: during counseling, the counselor should provide (explanations about) } \\
\hline Procedural aspects of counseling & 8 & $\begin{array}{l}\text { 'Information on procedure of counseling', } \\
\text { 'Punctuality' }\end{array}$ & 0.84 & 125 & 0.81 & 76 \\
\hline Sensitive communication & 8 & $\begin{array}{l}\text { 'Counselor takes counselee seriously', } \\
\text { 'Skill counselor' }\end{array}$ & 0.84 & 125 & 0.92 & 110 \\
\hline Emotional support & 5 & $\begin{array}{l}\text { 'Counselor shows understanding', 'Emotional } \\
\text { aspects of diagnostic procedure' }\end{array}$ & 0.81 & 124 & 0.80 & 93 \\
\hline $\begin{array}{l}\text { Assessment of susceptibility to } \\
\text { the disease }\end{array}$ & 3 & 'DNA-test done', 'Analysis of family history' & 0.64 & 121 & 0.70 & 89 \\
\hline \multicolumn{7}{|c|}{ Cancer-specific needs: during counseling, the counselor should explain .. } \\
\hline $\begin{array}{l}\text { Determination and implications } \\
\text { of carrying a cancer gene }\end{array}$ & 7 & $\begin{array}{l}\text { 'Possibilities of DNA-testing', 'Procedure of } \\
\text { DNA-testing' }\end{array}$ & 0.82 & 123 & 0.90 & 104 \\
\hline $\begin{array}{l}\text { (Emotional) aspects of counseling } \\
\text { for counselee and family }\end{array}$ & 5 & $\begin{array}{l}\text { 'Emotional consequences of counseling } \\
\text { for family', 'Emotional consequences of } \\
\text { counseling for counselee' }\end{array}$ & 0.79 & 123 & 0.83 & 102 \\
\hline $\begin{array}{l}\text { Counselee's own risk of develop- } \\
\text { ing cancer }\end{array}$ & 3 & $\begin{array}{l}\text { 'What to do if counselee is at increased risk', } \\
\text { 'Counselee's risk of developing cancer' }\end{array}$ & 0.79 & 121 & 0.85 & 109 \\
\hline Heredity of cancer in general & 3 & $\begin{array}{l}\text { 'Prevalence of hereditary cancer', } \\
\text { 'How cancer inherits in a family' }\end{array}$ & 0.76 & 125 & 0.73 & 116 \\
\hline
\end{tabular}

Perceived risk, with regard to the type of cancer the counselee was seeking advice for, was assessed using three visual analogue scales and one verbal scale (see the online Appendix B at http://www.interscience.wiley.com/jpages/15524825/suppmat/index.html). Counselees were asked to rate their perceived risk that hereditary cancer runs in their family, the counselee had inherited susceptibility to cancer, and that he/she would (re-)develop cancer in the future, on separate numerical scales from $0 \%$ to $100 \%$. The counselors answered similar numerical scales after the consultation, about their estimated risk for the counselee. The verbal scale assessed perceived absolute risk of (re-)developing cancer in the future, on a 5-point scale from 1, 'very low' to 5, 'very high.'

Perceived personal control was assessed using the Perceived Personal Control questionnaire (PPC) [Berkenstadt et al., 1999] that was translated in Dutch using a forward-backward procedure. It consists of nine items on subjective perception of how much control counselees believe to have with regard to their genetic problem, to be answered on a 3 -point scale ( 0 , 'not applicable'; 1, 'somewhat applicable'; 2 , 'highly applicable'). A total score was calculated as the mean of the scores on the relevant items (range scale, $0-2$ ). Internal consistencies of the scale were found to be high before $(\alpha=0.82)$ and after $(\alpha=0.83)$ the visit.

Generalized state anxiety. Current levels of generalized state anxiety were measured with the Dutch shortened 10item version of the State-Trait Anxiety Inventory (STAI) [Van der Ploeg et al., 1980; Spielberger, 1983]. The statements, worded either positively (e.g., 'I feel calm') or negatively (e.g., 'I feel strained'), measure how respondents currently feel on a four-point scale (from 1, 'not at all' to 4, 'very much so'). Total scores range from 10 to 40 . Internal consistencies for the scale were found to be high before $(\alpha=0.93)$ and after $(\alpha=0.94)$ the visit.

\section{Statistical Analyses}

Comparisons between participants (those with complete records vs. those returning the pre-visit questionnaire only; unaffected vs. affected counselees; counselees vs. counselors) and between pre- and post-visit measurements were analyzed using parametric or non-parametric tests, as appropriate. In 20 of the consultations that were conducted by two counselors, both counselors filled in a questionnaire and data from the clinical geneticist were used. Following Evans et al. [1994], counselees' risk perceptions were defined as accurate if they fell within a range from $50 \%$ lower to $50 \%$ higher than the counselor's estimations.

Descriptive statistics were used to report counselees' mean perception of fulfillment of their needs. Pre- and post-visit scores higher than 2.5 on needs were considered as indicating, respectively, (high) importance attached and being (very) satisfied.

Analysis of variance showed that neither post-visit measures nor counselees' perception of the extent to which pre-visit needs were addressed was significantly related to counselor. Counselor explained between $0.9 \%$ (perceived risk of (re-)developing cancer) and 4.4\% (PPC) of variance in outcome measures, and between $0.1 \%$ (heredity of cancer in general) and $3.6 \%$ (procedural aspects of counseling) of variance in addressing needs. Separate regression analyses were used to assess the association between fulfillment of each need and post-visit measures, controlling for pre-visit level. Each of these analyses was conducted within the subgroup of counselees with importance scores higher than 2.5 on the specific need. Where background variables were found to be significantly related to perceived importance of the need [Pieterse et al., 2005], these were controlled for in the analyses. Regression analyses were conducted in two steps. First, the need, pre-visit level of the criterion, and background variables as appropriate, were included. Second, the analysis was re-run with the need and other significant predictors only.

Significance was tested two-tailed at $\alpha=0.05$. If $25 \%$ or less of the values was missing, missing values were replaced by the mean on the (sub-)scales of the various needs, PPC and STAI.

\section{RESULTS \\ Participants}

Counselees. Of all eligible counselees, 204 (32.8\%) agreed to participate. Participants were on average 2.1 years older than decliners $(P=0.022)$ [Pieterse et al., 2005], but did not significantly differ in terms of gender, type of referral, type of cancer, or (family) history of cancer. For 128/145 (88.3\%) counselees who saw a counselor who did not receive feedback, pre- and post-visit data were available. Participants returning both questionnaires did not significantly differ in terms of gender, age, pre-visit levels of cognition, anxiety, or importance scores on needs compared to participants returning the pre-visit questionnaire only. Participants returning both 
TABLE II. Counselee Referral Pathway, Type of Cancer, History of Cancer, Course of Counseling, and Indication for DNA-Testing $(\mathrm{N}=128)^{*}$

\begin{tabular}{lrr}
\hline & $\mathrm{N}$ & $\%$ \\
\hline Referral pathway & & \\
Specialist & 64 & 52.0 \\
GP & 38 & 30.9 \\
Own initiative & 14 & 11.4 \\
Family & 7 & 5.7 \\
Type of cancer & 86 & 67.2 \\
Breast cancer & 22 & 17.2 \\
Colon cancer & 8 & 6.3 \\
Ovarian cancer & 7 & 5.5 \\
Breast and colon cancer & 7 & 5.5 \\
Other & 65 & 50.8 \\
Personal history of cancer & 63 & 49.2 \\
Counselee unaffected with cancer & 13 & 20.6 \\
Counselee affected with cancer & 50 & 79.4 \\
$\quad$ No relatives affected & & \\
$\quad$ Relatives also affected & 115 & 89.8 \\
Family history of cancer & 13 & 10.2 \\
1st or 2nd degree relatives with cancer & \\
No 1st or 2nd degree relatives with & & \\
cancer & & \\
DNA-test & 85 & 66.4 \\
Indicated & 19 \\
Not indicated & 19.8 \\
Uncertain &
\end{tabular}

*Summations may vary due to missing values.

andication for testing the counselee or a relative as judged after the visit.

${ }^{\mathrm{b}}$ Indication for DNA-test uncertain due to missing medical information.

questionnaires were more likely to be affected by cancer $(\mathrm{z}=-2.25, P=0.024)$ and they tended to have higher educational levels $(P=0.054)$.

Of the 128 participants returning both questionnaires, 120 $(93.8 \%)$ were female and $8(6.3 \%)$ were male. Mean age at the start of counseling was 44.5 years $(\mathrm{SD}=9.5$, range $18-$ 72 years). About half (54.7\%) of the participants had completed education up to high school level and the others $(45.3 \%)$ had completed higher vocational or university education. In Table II, details on referral pathway, type of cancer, and history of cancer are shown. Half of the counselees were unaffected people from cancer families. The counselees with affected relatives had one to four $(\mathrm{M}=1.5, \mathrm{SD}=0.8)$ firstdegree and one to eight $(\mathrm{M}=2.2, \mathrm{SD}=1.5)$ second-degree affected relatives. The counselees diagnosed with cancer had significantly more often an indication for a DNA-test than unaffected counselees $\left(\chi^{2}=13.8, P=0.001\right)$.
Counselors. Five clinical geneticists (four female, one male), four residents in clinical genetics (three female, one male; two of four finished their training during the study period), and five genetic nurses (all female; three of five finished their training) agreed to participate. The counselors were aged $29-46$ years $(\mathrm{M}=38.1 ; \mathrm{SD}=5.1)$. Response rate of the counselors on the post-visit questionnaire was $100 \%$. During 34 consultations, a clinical geneticist accompanied a resident $(\mathrm{N}=2)$ or a genetic nurse $(\mathrm{N}=32)$ in training. All other consultations $(\mathrm{N}=92)$ were conducted by one counselor. Moreover, it occurred twice that two counselees were seen together by a counselor.

\section{Outcome of the Initial Consultation}

Post-visit mean level of correct knowledge about hereditary breast and colon cancer was significantly higher compared to baseline (Table IV). Also, after the visit, the counselees perceived significantly higher personal control compared to baseline, and were significantly less anxious. The counselees' post-visit mean perceived numeric risk was significantly lower compared to baseline, with regard both to risk of hereditary cancer running in their family and to risk of having inherited an increased susceptibility to cancer themselves (Table IV). Similarly, post-visit perceived risk of (re-)developing cancer oneself was significantly lower compared to baseline, both when measured numerically and verbally.

Pre- to post-visit increase in mean levels of correct knowledge and perceived personal control did not significantly differ between unaffected and affected counselees (data not shown). In contrast, decrease in mean level of anxiety was significantly lower for those diagnosed with cancer $(\mathrm{t}=-1.99, P=0.049)$. Decrease in mean levels of numeric risk perceptions of hereditary cancer running in the family, having inherited a mutation and of (re-)developing cancer, was significantly lower in counselees diagnosed with cancer $(\mathrm{t}=-2.71, P=0.008$; $\mathrm{t}=-3.35, P=0.001 ; \mathrm{t}=-3.83, P=0.000$, respectively). When measured verbally, decrease in risk perception of (re-)developing cancer did not significantly differ $(t=-1.48, \mathrm{~ns})$.

A comparison between the counselees' perceptions of risk and how the counselor estimated the respective counselees' risk, showed that counselees' pre-visit mean perceptions were significantly higher. After the visit, only the counselees' mean estimation of probability that hereditary cancer runs in their family was no longer significantly different from the counselors'.

As regards to the counselees' accuracy, their pre-visit perceptions were most close to the counselors' estimations with respect to risk of hereditary cancer running in the family and least regarding their own risk of cancer (Table V). After

TABLE III. Importance Ratings on the Needs and Number of Counselees Reporting on Satisfaction (Frequencies), and Their Satisfaction Versus Dissatisfaction About the Fulfillment of These Needs During the Visit (\%)

\begin{tabular}{|c|c|c|c|c|}
\hline Need & $\begin{array}{l}\text { Counselees considering } \\
\text { needs important prior } \\
\text { to counseling }(\mathrm{N})\end{array}$ & $\begin{array}{l}\text { Counselees } \\
\text { reporting } \\
\text { satisfaction }^{\mathrm{a}}(\mathrm{N})\end{array}$ & $\begin{array}{c}\text { Satisfactorily } \\
\text { addressed }^{\mathrm{a}}(\%)\end{array}$ & $\begin{array}{l}\text { Not satisfactorily } \\
\text { addressed }^{\mathrm{a}}(\%)\end{array}$ \\
\hline \multicolumn{5}{|c|}{ Generic needs: during counseling, the counselor provided (explanations about)... } \\
\hline Sensitive communication & 125 & 121 & 97.5 & 2.5 \\
\hline Procedural aspects of counseling & 119 & 101 & 92.1 & 7.9 \\
\hline Assessment of susceptibility to cancer & 112 & 79 & 93.7 & 6.3 \\
\hline Emotional support & 83 & 77 & 76.6 & 23.4 \\
\hline \multicolumn{5}{|c|}{ Cancer-specific needs: during counseling, the counselor provided explanations about... } \\
\hline Carriership of mutated cancer gene & 119 & 108 & 81.5 & 18.5 \\
\hline Counselee's own risk of developing cancer & 110 & 95 & 76.8 & 23.2 \\
\hline (Emotional) aspects of counseling & 103 & 87 & 79.3 & 20.7 \\
\hline Heredity of cancer in general & 67 & 60 & 88.3 & 11.7 \\
\hline
\end{tabular}

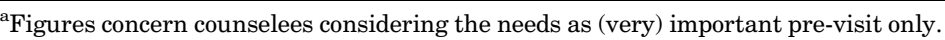


TABLE IV. Counselees' Mean Levels on Pre- and Post-Visit Measures and Counselors' Mean Perceptions of Risk Regarding the Counselees $(\%)$

\begin{tabular}{|c|c|c|c|c|c|c|c|c|}
\hline & \multirow[b]{2}{*}{ Scale } & \multirow[b]{2}{*}{$\mathrm{N}$} & \multicolumn{2}{|c|}{ Pre-visit } & \multicolumn{2}{|c|}{ Post-visit } & \multicolumn{2}{|c|}{ Counselor's risk estimation ${ }^{\mathrm{c}}$} \\
\hline & & & M & SD & M & SD & M & $\mathrm{SD}$ \\
\hline \multicolumn{9}{|l|}{ Correct knowledge $^{\mathrm{a}}$} \\
\hline Hereditary breast cancer & $0-7$ & 93 & 4.81 & 1.50 & $6.01 * * *$ & 1.31 & & \\
\hline Hereditary colon cancer & $0-6$ & 22 & 3.64 & 0.79 & $4.45^{* *}$ & 0.91 & & \\
\hline $\mathrm{PPC}^{\mathrm{b}}$ & $0-2$ & 118 & 1.10 & 0.44 & $1.36 * * *$ & 0.45 & & \\
\hline STAI $^{b}$ & $10-40$ & 120 & 20.7 & 6.4 & $18.6^{* * *}$ & 6.3 & & \\
\hline \multicolumn{9}{|l|}{ Perceived numeric risk ${ }^{b}$} \\
\hline Hereditary cancer in family & $0-100 \%$ & 121 & 57.1 & 22.5 & $50.8^{* *}$ & 27.4 & $49.5^{\dagger}$ & 27.8 \\
\hline Carrying a mutation & $0-100 \%$ & 119 & 56.0 & 21.2 & $47.4^{* * *}$ & 26.2 & $35.2^{\dagger \dagger, \dagger}$ & 24.3 \\
\hline (Re-)developing cancer oneself & $0-100 \%$ & 117 & 52.9 & 23.3 & $46.4^{* * * *}$ & 24.5 & $24.1^{\dagger, \dagger}$ & 15.9 \\
\hline $\begin{array}{l}\text { Perceived absolute risk } \\
\quad \text { (re-)developing cancer }\end{array}$ & $1-5$ & 115 & 3.65 & 0.84 & $3.49^{*}$ & 0.86 & & \\
\hline
\end{tabular}

${ }^{a}$ Wilcoxon signed ranks test.

${ }^{\mathrm{b}} T$-test for paired samples.

'The counselors' mean levels of estimated risk was compared to the counselees' pre- and post-visit perceptions.

Pre- versus post-visit risk perceptions within counselees: $* P<0.05 ; * * P<0.01$; *** $P<0.001$

Counselees' pre-visit versus counselors’ post-visit risk perceptions: ${ }^{\dagger} P<0.05 ;{ }^{\dagger} P<0.001$.

Counselees' versus counselors' post-visit risk perceptions: ${ }^{\star} P<0.001$.

the visit, there were overall less overestimators and more accurate estimators compared to baseline, and this increase in accuracy was significant for perceived risk of hereditary cancer running in the family $(\mathrm{z}=-2.70, P=0.007)$ and for (re-)developing cancer oneself $(\mathrm{z}=-2.68, P=0.007)$.

\section{Need Fulfillment}

Results show that overall, needs considered as important were addressed satisfactorily during the visit in counselees' perception (Table III). Nevertheless, relatively fewer counselees were satisfied about the emotional support they received, and one-fifth of those who attached importance to receiving explanations about (emotional) aspects of counseling and about their own risk of cancer, were not satisfied about the extent to which these needs were addressed.

\section{Influence of Need Fulfillment on Visit Outcome}

Results showed that addressing needs that were considered as important pre-visit, significantly affected the outcome of the initial visit, controlling for baseline (Table VI). Specifically, increase in mean level of perceived personal control was significantly related to better fulfilling each of the generic and cancer-specific needs, in counselees' perception. Also, decrease in mean level of anxiety was significantly associated to addressing more satisfactorily the counselees' need for emotional support and need for explanations on their own risk of cancer. Similarly, a lower mean post-visit perception of risk of hereditary cancer running in the family was significantly related to better addressing the counselees' need for emotional support in their perception. In contrast, higher mean risk perceptions of having inherited a mutation and of (re-)developing cancer (measured numerically) were significantly related to being more satisfied about the explanations received on aspects of DNA-testing and consequences of carrying a cancer gene. These associations were not significant within the selection of counselees considering these explanations as important pre-visit who were affected $(\mathrm{N}=56)$ or who had an indication for a DNA-test $(\mathrm{N}=79$ ) (data not shown). The association between fulfilling this need for information and perceived risk of carrying a mutation was significant within the selection of unaffected counselees considering these explanations as important pre-visit $(\mathrm{N}=63 ; \mathrm{r}=0.21, P=0.027)$. The extent to which major needs had been addressed was not significantly related to post-visit level of correct knowledge.

Analyses were re-ran in the selection of female counselees who sought counseling for breast/ovarian cancer and who considered, pre-visit, the various needs as important. Results were similar as described above (data not shown). In addition, analyses were re-ran in the whole sample of counselees, controlling for pre-visit importance scores on the various needs. Comparable significant results were found for perceived personal control, anxiety, and risk perceptions (data not shown), and results showed that importance scores were unrelated to outcome measures. Moreover, it was found that lower post-visit anxiety was significantly associated with counselees' satisfaction about explanations on hereditary cancer in general (Beta $=-0.16, P=0.025)$. Again, pre-visit importance score was unrelated to post-visit anxiety. In contrast, findings showed that higher perceived absolute and numerical risk of (re-)developing cancer was significantly related to higher pre-visit importance scores on need for

TABLE V. Accuracy (\%) of Counselees' Pre- and Post-Visit Risk Perceptions ( $\mathrm{N}=128)$

\begin{tabular}{lccc}
\hline Perceived numeric risk & Understimators & Close estimators & Overestimators \\
\hline Pre-visit & & & \\
Hereditary cancer in family & 7.6 & 55.9 & 36.4 \\
Carrying a mutation & 3.4 & 37.1 & 59.5 \\
(Re-)developing cancer oneself & 6.9 & 14.7 & 78.4 \\
Post-visit & 12.5 & 58.3 & 29.2 \\
Hereditary cancer in family & 6.8 & 39.8 & 53.4 \\
Carrying a mutation & 5.1 & 31.6 & 63.2 \\
(Re-)developing cancer oneself & & & \\
\hline
\end{tabular}


TABLE VI. Association Between Addressing Major Needs and Post-Visit Measures, Controlling for Pre-Visit Level

\begin{tabular}{|c|c|c|c|c|}
\hline & \multicolumn{4}{|c|}{ Generic needs } \\
\hline & $\begin{array}{l}\beta \text { Procedural aspects } \\
\quad(\mathrm{N}=101)\end{array}$ & $\begin{array}{c}\beta \text { Sensitive } \\
\text { communication } \\
(\mathrm{N}=121)\end{array}$ & $\begin{array}{c}\beta \text { Emotional support } \\
(\mathrm{N}=77)\end{array}$ & $\begin{array}{l}\beta \text { Assessment of cancer } \\
\text { susceptibility }(N=79)\end{array}$ \\
\hline $\begin{array}{l}\text { Correct knowledge about } \\
\text { hereditary cancer }\end{array}$ & 0.01 & 0.02 & 0.12 & 0.04 \\
\hline $\mathrm{PPC}$ & $* * 0.28$ & $* * 0.27$ & $* * 0.34$ & $* * 0.32$ \\
\hline STAI & -0.12 & -0.05 & $* *-0.21$ & -0.04 \\
\hline \multicolumn{5}{|l|}{ Perceived numeric risk } \\
\hline Hereditary cancer in family & -0.03 & -0.02 & $*-0.14$ & 0.07 \\
\hline Carrying a mutation & 0.01 & 0.00 & -0.08 & 0.13 \\
\hline (Re-)developing cancer & -0.01 & 0.03 & -0.02 & 0.12 \\
\hline $\begin{array}{l}\text { Perceived absolute risk } \\
\text { (re-)developing cancer }\end{array}$ & -0.03 & 0.01 & -0.18 & 0.00 \\
\hline
\end{tabular}

\begin{tabular}{|c|c|c|c|c|}
\hline & \multicolumn{4}{|c|}{ Cancer-specific needs } \\
\hline & $\begin{array}{l}\beta \text { Being a carrier of a } \\
\text { mutated cancer gene } \\
(N=108)\end{array}$ & $\begin{array}{c}\beta \text { (Emotional) aspects } \\
\text { of counseling } \\
(\mathrm{N}=87)\end{array}$ & $\begin{array}{l}\beta \text { Counselee's own risk } \\
\text { of developing cancer } \\
\quad(N=95)\end{array}$ & $\begin{array}{l}\beta \text { Heredity of cancer } \\
\text { in general } \\
(\mathrm{N}=60)\end{array}$ \\
\hline $\begin{array}{l}\text { Correct knowledge about } \\
\text { hereditary cancer }\end{array}$ & 0.12 & -0.05 & 0.07 & 0.11 \\
\hline PPC & $* * * 0.32$ & $* * 0.29$ & $* * 0.28$ & $* * 0.42$ \\
\hline STAI & -0.03 & -0.07 & $*-0.16$ & -0.14 \\
\hline Perceived numeric risk & & & & \\
\hline Hereditary cancer in family & 0.13 & -0.11 & 0.04 & -0.03 \\
\hline Carrying a mutation & $* 0.16$ & -0.08 & -0.01 & -0.05 \\
\hline (Re-)developing cancer & $* 0.15$ & 0.00 & 0.12 & -0.02 \\
\hline $\begin{array}{l}\text { Perceived absolute risk } \\
\text { (re-)developing cancer }\end{array}$ & 0.12 & -0.01 & 0.10 & -0.05 \\
\hline
\end{tabular}

${ }^{a}$ Controlled for gender, level of education, and number of first-degree affected relatives.

${ }^{\mathrm{b}}$ Controlled for personal history of cancer.

$* P<0.05$.

*** $P<0.01$.

$* * * P<0.001$.

assessment of susceptibility to cancer (Beta $=0.19, P=0.030)$ and need for explanations on own risk of cancer $($ Beta $=0.15$, $P=0.017$ ), respectively. In both cases, post-visit personal cancer risk perceptions were unrelated to fulfillment of these needs during the visit.

\section{DISCUSSION}

In initial visits, cancer genetic counseling primarily aims at educating counselees about cancer risk and preventive strategies. Results suggest that this aim is achieved, in so far that counselees have more correct knowledge about hereditary cancer and perceive more control after the visit compared to baseline, irrespective of health state. These results confirm earlier findings on knowledge in affected [Randall et al., 2001] and unaffected [Lerman et al., 1997] counselees for hereditary breast cancer, as well as for hereditary colon cancer [Collins et al., 2000], and also confirm findings on personal control in counselees for various genetic conditions [Berkenstadt et al., 1999]. After the visit, counselees also were less anxious, a result consistent with findings among affected [Julian-Reynier et al., 1998] and unaffected [Cull et al., 1999; Julian-Reynier et al., 1999; Watson et al., 1999] women seeking counseling for hereditary breast cancer. Nevertheless, decrease in anxiety was less for affected counselees. These counselees may fear recurrence of their cancer or occurrence of another primary cancer. Moreover, the likelihood of hereditary cancer in their families is probably greater, as affected counselees more often had an indication for DNA-testing.
In line with earlier findings [Croyle and Lerman, 1999; Collins et al., 2000; Bish et al., 2002], counselees had inflated risk perceptions at baseline. Even though lower after the visit, inaccuracies of risk estimations persisted. These results confirm findings in earlier studies amongst unaffected women seeking hereditary breast cancer counseling [Lerman et al., 1995; Cull et al., 1999; Lobb et al., 2003] and amongst affected and unaffected men and women seeking counseling for hereditary colon cancer [Collins et al., 2000]. Post-visit perception of personal risk of cancer was decreased when measured both numerically and verbally. Measurement of risk that most closely captures the manner in which it is represented in individuals' minds is still under debate [Woloshin et al., 1999], yet this finding suggests an actually lowered risk perception. Results on accuracy of risk may be somewhat distorted, as counselors' estimations of risk were used as a proxy for actual risk, while these may deviate from actual risks. What these results do show is that counselees' mean numeric risk perceptions were mutually very similar, indicating that counselees may fail to understand how mutations are inherited and that the penetrance of mutated cancer genes is incomplete.

\section{Fulfillment of Needs During the Visit}

Comparable high levels of satisfaction with the care provided by clinical geneticists, including communication and risk assessment, were reported in a pilot study amongst 36 counselees for hereditary cancer [Bleiker et al., 1997]. Nevertheless, 
around one-fifth of the counselees in the present study were not satisfied with the emotional support they received, nor with explanations on (emotional) aspects of counseling, or their own risk of cancer. Similar results were reported in a study on genetic counseling including heterogeneous conditions, in which at least a quarter of the counselees reported that their expectations regarding information, explanations, and reassurance were not met during counseling [Michie et al., 1997a]. Likewise, dissatisfaction with information received relating to screening and prevention for themselves, was reported in a study on hereditary colon cancer counseling [Collins et al., 2000]. Talking about cancer susceptibility may be an anxietyprovoking and tense experience due to the nature and the implications of the information received. This may explain why even though counselees consider emotional aspects as comparatively less important prior to counseling, relatively fewer of them considered these fulfilled during the encounter, compared to other needs. Alternatively, dissatisfaction may be due to counselors underestimating counselees' needs in that respect. This would be concordant with Lobb et al. [2002] finding that counselors' behavior was not dependent on the levels of anxiety of affected and unaffected women they counseled for hereditary breast cancer. Counselees' dissatisfaction about explanations on their own risk of cancer may reflect inadequacies in counselors' explanations. However, information provided during genetic counseling is often imbued with all sorts of unpredictability, and many counselees may leave the consultation experiencing their situation as highly uncertain [Van Zuuren et al., 1997]. Therefore, counselees' dissatisfaction may as well reflect feelings about the remaining uncertainty that inevitably surrounds the question whether they will or will not (re-)develop cancer. That is a question that counselors are unable to answer.

\section{Influence of Addressing Needs on the Visit Outcome}

The finding that addressing counselees' major needs results in higher perceptions of control and, to some extent, in lower levels of anxiety, supports and extends earlier findings. Specifically, Berkenstadt et al. [1999] found that counselees for various genetic conditions felt more control after their visit, the better their cognitive, behavioral, decisional, and emotional expectations were fulfilled. Also, female cancer patients felt less anxious when they were more satisfied with the counseling consultation [Julian-Reynier et al., 1998]. Counselees also felt less anxious when they perceived their expectations on receiving reassurance or advice were met [Michie et al., 1997a]. Importantly, counseling that results in a greater reduction in anxiety by addressing more satisfactorily counselees' needs may facilitate surveillance behavior [Kash et al., 1995]. Providing adequate emotional support appeared to be related to a more accurate perception of risk that hereditary cancer runs in the family, providing some support for Lerman et al. [1995]'s contention that efforts to counsel unaffected women about their breast cancer risks are unlikely to be effective unless their anxious preoccupations with breast cancer are also addressed. In contrast, providing more explanations on DNA-testing and consequences of carrying a cancer gene appeared to increase perceptions of personal risk of cancer, especially in unaffected counselees. As this association was not found when personal cancer risk was assessed verbally, the numeric assessment may partly stem from counselees' recall of numerical information that is provided in discussing DNA-testing and risks associated with inherited mutations. It is surprising that unaffected counselees, who have less often an indication for DNA-testing, perceive higher risk of carrying a mutation when their need for explanations on aspects of DNA-testing are better fulfilled. Possibly, these counselees do not become convinced that they are not at increased risk. Otherwise, discussing aspects of DNA-testing and increased risk related to cancer genes, in particular where a DNA-test is not indicated, may induce higher risk perceptions. Noticeably, results suggest that counselees who attach greater importance to the assessment of cancer susceptibility and own cancer risk perceive higher personal risk of cancer after the visit, irrespective of how well these needs were fulfilled. The provision of information in itself seems insufficient in reducing these risk perceptions. Furthermore, the findings lend support to the proposition that information may be helpful in decreasing anxiety, as Lobb et al. [2004] found.

\section{Limitations}

A number of limitations should be noted. First, this study was based on one clinic only, only one-third $(32.8 \%)$ of the eligible counselees participated, and these were on average 2.1 years older than decliners [Pieterse et al., 2005]. Most (93.8\%) of the participating counselees were female and a majority $(67.2 \%)$ sought counseling for hereditary breast cancer. As a result, the sample was heterogeneous in terms of type of cancer in particular. As findings within the heterogeneous sample and within the sample of females seeking counseling for breast/ ovarian cancer were similar, it appears that the findings may be generalized to the larger population of female counselees for breast/ovarian cancer. Furthermore, almost half (45.3\%) of the counselees had higher educational levels, a proportion that is appreciably high compared to a representative sample of patients (25 years and older) of general practitioners in the Netherlands, of which $22.3 \%$ had completed higher vocational or university education [Van Lindert et al., 2004]. It is, however, similar to the proportion $(48 \%)$ found in another study on cancer genetic counseling amongst Dutch counselees [Van Asperen et al., 2002]. Apparently, individuals with lower educational levels still make relatively less use of cancer genetic counseling. Cell sizes were too small to investigate the potential influence of different types of cancer. More research is indicated to assess whether addressing pre-visit needs is beneficial also to males, unaffected counselees, those with lower levels of education, and those with a referral for a type of cancer other than breast cancer.

Second, fourteen counselors were included in the study, each of whom may have affected counseling differently. Yet, counselees' scores on outcome measures and their reported needs fulfillment were only slightly related to the counselor they had seen. So, variability in counselors does not in itself seem to constrain the generalization of the results.

Third, using a pre-post design, it is not possible to determine how much of the observed changes are attributable to the visit only. However, counselees answered the pre- and postvisit questionnaires within a week before and a day after the consultation, respectively. It is thus likely that changes in correct knowledge, perceived control, anxiety, and risk perceptions are due to the specific information that counselees received during the visit or that they gathered, prompted by their attendance at the clinic.

\section{CONCLUSION}

In conclusion, our results confirm that the initial cancer genetic counseling visit is a positive experience, leading to an increase in correct knowledge about hereditary cancer and perceptions of personal control, and reduced levels of anxiety and risk perceptions. Yet, these decreases in anxiety and risk perceptions are smaller for cancer patients, so both unaffected and affected counselees need careful counseling. Also, explanations on inheritance and penetrance of mutated genes may need more detailing, as counselees did not appear to fully 
grasp these notions. We have further shown that overall counselors address counselees' needs satisfactorily. Nonetheless, counselors may need to pay more attention to counselees' needs relating to emotional aspects of counseling, and to provide better suited explanations about counselees' own risk of cancer. Moreover, our findings reveal that the better counselees consider their major pre-visit needs to be fulfilled, the more personal control they perceive, and the less anxious they feel. As there are indications that women attach great importance to specific needs prior to counseling [Pieterse et al., 2005 , in press], counselors may need to adapt their counseling to female counselees accordingly, in order to achieve a more effective service. Empirical data are necessary to determine whether providing more adequate emotional support indeed results in a more accurate perception of (personal) risk of cancer, as our findings suggest, and whether discussing aspects of inheritance increases personal risk perceptions. In addition, as a primary goal of counseling is education about cancer risk, more research is needed to elucidate what may cause counselees' dissatisfaction about the explanations they received about their own risk of cancer.

\section{ACKNOWLEDGMENTS}

We are thankful to the participating counselees and clinical geneticists, residents in clinical genetics, and genetic nurses of the Department of Medical Genetics at the University Medical Centre, Utrecht, the Netherlands, who made this study possible.

\section{REFERENCES}

Bensing J. 2000. Bridging the gap. The separate worlds of evidence-based medicine and patient-centered medicine. Patient Educ Couns 39:17-25.

Berkenstadt M, Shiloh S, Barkai G, Bat-Miriam Katznelson M, Goldman B. 1999. Perceived personal control (PPC): A new concept in measuring outcome of genetic counseling. Am J Med Genet 82:53-59.

Bish A, Sutton S, Jacobs C, Levene S, Ramirez A, Hodgson S. 2002. Changes in psychological distress after cancer genetic counselling: A comparison of affected and unaffected women. Br J Cancer 86:43-50.

Bleiker EM, Aaronson NK, Menko FH, Hahn DE, Van Asperen CJ, Rutgers EJ, Ten Kate LP, Leschot NJ. 1997. Genetic counseling for hereditary cancer: A pilot study on experiences of patients and family members. Patient Educ Couns 32:107-116.

Burke W, Culver JO, Bowen D, Lowry D, Durfy S, McTiernan A, Andersen MR. 2000. Genetic counseling for women with an intermediate family history of breast cancer. Am J Med Genet 90:361-368.

Claes E, Evers-Kiebooms G, Boogaerts A, Decruyenaere M, Denayer L, Legius E. 2003. Communication with close and distant relatives in the context of genetic testing for hereditary breast and ovarian cancer in cancer patients. Am J Med Genet 116A:11-19.

Clayton EW. 2003. Ethical, legal, and social implications of genomic medicine. N Engl J Med 349:562-569.

Collins V, Halliday J, Warren R, Williamson R. 2000. Assessment of education and counselling offered by a familial colorectal cancer clinic. Clin Genet 57:48-55.

Croyle RT, Lerman C. 1999. Risk communication in genetic testing for cancer susceptibility. J Natl Cancer Inst 25:59-66.

Cull A, Anderson ED, Campbell S, Mackay J, Smyth E, Steel M. 1999. The impact of genetic counselling about breast cancer risk on women's risk perceptions and levels of distress. Br J Cancer 79:501-508.

Evans DGR, Blair V, Greenhalgh R, Hopwood P, Howell A. 1994. The impact of genetic counselling on risk perception in women with a family history of breast cancer. Br J Cancer 70:934-938.

Finkler K, Skrzynia C, Evans JP. 2003. The new genetics and its consequences for family, kinship, medicine and medical genetics. Soc Sci Med 57:403-412.

Hallowell N, Murton F, Statham H, Green JM, Richards MPM. 1997. Women's need for information before attending genetic counselling for familial breast or ovarian cancer: A questionnaire, interview, and observational study. Br Med J 314:281-283.
Julian-Reynier C, Eisinger F, Chabal F, Aurran Y, Bignon YJ, Noguès C, Machelard M, Maugard C, Vennin P, Sobol H. 1998. Time elapsing from cancer diagnosis and anxiety in women attending cancer genetic clinics. Oncol Rep 5:885-888.

Julian-Reynier CJ, Eisinger F, Chabal F, Aurran Y, Bignon YJ, MachelardRoumagnac M, Maugard C, Noguès C, Vennin P, Sobol H. 1999. Cancer genetic consultation and anxiety in healthy consultees. Psychol Health 14:379-390.

Kash KM, Holland JC, Osborne MP, Miller DG. 1995. Psychological counseling strategies for women at risk of breast cancer. J Natl Cancer Inst 17:73-79.

Lerman C, Lustbader E, Rimer B, Daly M, Miller S, Sands C, Balshem A. 1995. Effects of individualized breast cancer risk counseling: A randomized trial. J Natl Cancer Inst 87:286-292.

Lerman C, Biesecker B, Benkendorf JL, Kerner J, Gomez-Caminero A, Hughes C, Reed MM. 1997. Controlled trial of pretest education approaches to enhance informed decision-making for BRCA1 gene testing. J Natl Cancer Inst 89:148-157.

Lobb EA, Butow PN, Meiser B, Barratt A, Gaff C, Young MA, Kirk J, Suthers GK, Tucker K. 2002. Tailoring communication in consultations with women from high risk breast cancer families. Br J Cancer 87:502508.

Lobb EA, Butow PN, Meiser B, Barratt A, Gaff C, Young MA, Kirk J, Gattas M, Gleeson M, Tucker K. 2003. Women's preferences and consultants' communication of risk in consultations about familial breast cancer: Impact on patient outcomes. J Med Genet 40:e56.

Lobb EA, Butow PN, Barratt A, Meiser B, Gaff C, Young MA, Haan E, Suthers G, Gattas M, Tucker K. 2004. Communication and informationgiving in high-risk breast cancer consultations: Influence on patient outcomes. Br J Cancer 90:321-327.

Meiser B, Halliday JL. 2002. What is the impact of genetic counselling in women at increased risk of developing hereditary breast cancer? A metaanalytic review. Soc Sci Med 54:1463-1470.

Michie S, Marteau TM, Bobrow M. 1997a. Genetic counselling: The psychological impact of meeting patients' expectations. J Med Genet 34:227-241.

Michie S, McDonald V, Marteau TM. 1997b. Genetic counselling: Information given, recall and satisfaction. Patient Educ Couns 32:101-106.

Michie S, Weinman J, Marteau TM. 1998. Genetic counselors' judgments of patient concerns: Concordance and consequences. J Genet Couns 7:219231.

Pieterse A, Van Dulmen S, Ausems M, Schoemaker A, Beemer F, Bensing J. 2005. QUOTE-geneca: Development of a counselee-centered instrument to measure needs and preferences in genetic counseling for hereditary cancer. Psychooncology 14:361-375.

Pieterse AH, Van Dulmen AM, Beemer FA, Ausems MGEM, Bensing JM. 2005. Tailoring communication in cancer genetic counseling through individual video-supported feedback: A controlled pretest-posttest design. Patient Educ Couns (in press).

Randall J, Butow P, Kirk J, Tucker K. 2001. Psychological impact of genetic counselling and testing in women previously diagnosed with breast cancer. Intern Med J 31:397-405.

Roter D. 2000. The enduring and evolving nature of the patient-physician relationship. Patient Educ Couns 39:5-15.

Spielberger CD. 1983. Manual of the State-Trait anxiety inventory. Palo Alto, CA: Consulting Psychologists Press.

Stewart MA. 1995. Effective physician-patient communication and health outcomes: A review. Can Med Assoc J 152:1423-1433.

Stewart M, Brown JB, Donner A, McWhinney IR, Oates J, Weston WW, Jordan J. 2000. The impact of patient-centered care on outcomes. J Fam Pract 49:796-804.

Tambor ES, Bernhardt BA, Rodgers J, Holtzman NA, Geller G. 2002. Mapping the human genome: An assessment of media coverage and public reaction. Genet Med 4:31-36.

Van Asperen CJ, Van Dijk S, Zoeteweij MW, Timmermans DR, De Bock GH, Meijers-Heijboer EJ, Niermeijer MF, Breuning MH, Kievit J, Otten W. 2002. What do women really want to know? Motives for attending familial breast cancer clinics. J Med Genet 39:410-414.

Van der Ploeg HM, Defares PB, Spielberger CD. 1980. Handleiding bij de Zelfbeoordelings Vragenlijst (ZBV) [Manual of the Dutch version of the State Trait Anxiety Inventory]. Lisse, The Netherlands: Swets and Zeitlinger.

Van Lindert H, Droomers M, Westert GP. 2004. Een kwestie van verschil: Verschillen in zelfgerapporteerde leefstijl, gezondheid en zorggebruik [A 
matter of difference: Differences in self-reported lifestyle, health and use of care]. Utrecht, The Netherlands: Nivel.

Van Zuuren FJ, Van Schie EC, Van Baaren NK. 1997. Uncertainty in the information provided during genetic counseling. Patient Educ Couns 32:129-139

Watson M, Lloyd S, Davidson J, Meyer L, Eeles R, Ebbs S, Murday V. 1999. The impact of genetic counselling on risk perception and mental health in women with a family history of breast cancer. Br J Cancer 79:868874.

Woloshin S, Schwartz LM, Black WC, Welch HG. 1999. Women's perceptions of breast cancer risk: How you ask matters. Med Decis Making 19:221229.

Wooster R, Weber BL. 2003. Breast and ovarian cancer. N Engl J Med 348:2339-2347. 